\title{
A short history of ocean acidification science in the 20th century: a chemist's view
}

\author{
P. G. Brewer \\ Monterey Bay Aquarium Research Institute (MBARI), 7700 Sandholdt Road, Moss Landing, CA 95039, USA \\ Correspondence to: P. G. Brewer (brpe@ mbari.org)
}

Received: 12 February 2013 - Published in Biogeosciences Discuss.: 27 May 2013

Revised: 25 September 2013 - Accepted: 22 October 2013 - Published: 19 November 2013

\begin{abstract}
This review covers the development of ocean acidification science, with an emphasis on the creation of ocean chemical knowledge, through the course of the 20th century. This begins with the creation of the $\mathrm{pH}$ scale by Sørensen in 1909 and ends with the widespread knowledge of the impact of the "High $\mathrm{CO}_{2}$ Ocean" by then well underway as the trajectory along the IPCC scenario pathways continues. By mid-century the massive role of the ocean in absorbing fossil fuel $\mathrm{CO}_{2}$ was known to specialists, but not appreciated by the greater scientific community. By the end of the century the trade-offs between the beneficial role of the ocean in absorbing some $90 \%$ of all heat created, and the accumulation of some $50 \%$ of all fossil fuel $\mathrm{CO}_{2}$ emitted, and the impacts on marine life were becoming more clear. This paper documents the evolution of knowledge throughout this period.
\end{abstract}

\section{Introduction}

"An important scientific innovation rarely makes its way by gradually winning over and converting its opponents: it rarely happens that Saul becomes Paul. What does happen is that its opponents gradually die out, and that the growing generation is familiarized with the ideas from the beginning." (Max Planck, New York, 1949)

This paper is an attempt to chart the course of what is now known as "Ocean Acidification" science through the years of the 20th century and to examine how critical concepts were formed and tested. For the very early years the papers are few, but by late 2003, the time of planning for the first transformational "Ocean in a High $\mathrm{CO}_{2}$ World" meeting to be held in Paris in 2004 (Cicerone et al., 2004), the influential recent papers crowd in and the distinction between "history" and "re- cent" becomes so blurred that mention is inappropriate here. The focus is on the technical trail of pioneers who sought to quantify the oceanic $\mathrm{CO}_{2}$ system chemistry and reveal the substance of change in the ocean. Regrettably it is not possible here to address the large parallel literature on carbon cycle modeling and tracer geochemistry, nor on the basic development of marine animal physiology and $\mathrm{pH}$ change.

The quotation from Max Planck above is illuminating, for as we work through the growth of ideas, perceptions, positions taken, etc., in this field, it is clear that the sense of ocean acidification as an environmental threat has taken many decades to form. Throughout much of the 20th century, the dominant focus has been the beneficial process of oceanic $\mathrm{CO}_{2}$ uptake, which has enormously ameliorated climate change. The concept of "too much of a good thing" has been late in developing and was triggered only by some key events, and the oceanic sink for heat and $\mathrm{CO}_{2}$ is still critical as the primary buffer against climate change.

Any history of oceanic $\mathrm{pH}$ as a measurable property must begin with the creation of the pH scale in 1909 by S. P. L. Sørensen. Sørensen was concerned with the effect of hydrogen ions on enzymatic processes and was employed by the Carlsberg Laboratory (Fig. 1). There was no useful metric for this and so he sought a way forward. He used as a point of reference the electrode potential generated by contact of the two purest substances he could find: that created by the interface between hydrogen gas and platinum metal. This takes the form of the hydrogen-Pt electrode, which when the partial pressure of hydrogen gas is 1 , atmosphere leads to the simple notation given by Jensen (2004) as

$$
E=2.3(R T / F) \log \left(1 /\left[\mathrm{H}^{+}\right]\right)=0.0577 \log \left(1 /\left[\mathrm{H}^{+}\right]\right),
$$




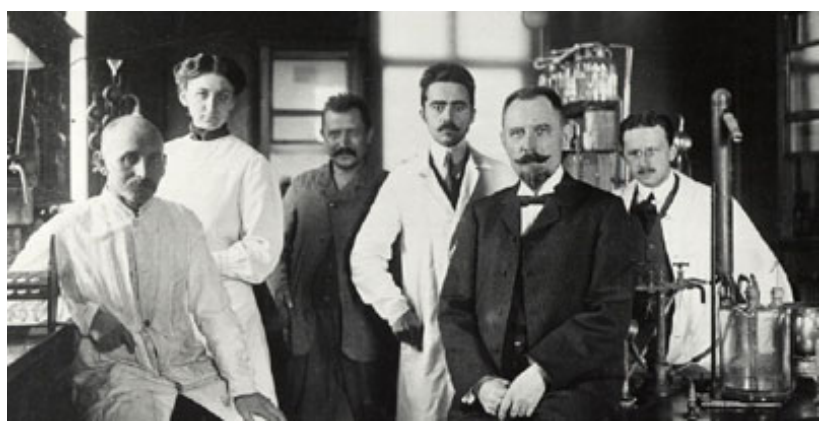

Fig. 1. The founder of the $\mathrm{pH}$ scale: Soren Peter Lauritz Sørensen (center right) in the Carlsberg Copenhagen laboratory. The author recalls with pleasure the abundant supply of Carlsberg beer on the RRS Discovery on the International Indian Ocean Expedition of the early 1960s, facilitated no doubt by Sørensen's early work.

where $R$ is the gas constant, $F$ is the Faraday constant and $T$ is the standard temperature of $298 \mathrm{~K}$, with a potential proportional to $-\log \left[\mathrm{H}^{+}\right]$, and hence the system we use today. Not everyone was pleased, for few think easily in terms of the negative log of base 10 as the basis for a common property. For example Clark (1928) notes, "it is unfortunate that a mode of expression so well adapted to the treatment of various relations should conflict with a mental habit. $\left[\mathrm{H}^{+}\right]$represents the hydrogen ion concentration, the quantity usually thought of in conversation when we speak of increases or decreases in acidity. $\mathrm{pH}$ varies inversely as $\mathrm{H}^{+}$. This is confusing." Many ocean scientists would agree.

The modern definition of $\mathrm{pH}$ (Buck et al., 2002) derives from this but with difficulty since "it involves a single ion quantity, the activity of the hydrogen ion, which is immeasurable by any thermodynamically valid method and requires a convention for its evaluation." It is no wonder then that ocean scientists for the vastly greater part of the last century abjured $\mathrm{pH}$ as a direct measurement (although many attempts were made), but in doing so apparently failed to communicate effectively to others the extraordinary changes taking place in the ocean. The accurate direct measurement of seawater $\mathrm{pH}$ remains a challenge almost a century later (Dickson, 1993).

Sørensen was one of the most accomplished chemists of his day, and objectively a "card-carrying" ocean scientist well before his creation of the $\mathrm{pH}$ scale. He was previously directly responsible for the chemical analyses of the series of samples that defined the famous Hydrographical Tables (Forch et al, 1902) that provided the basis for the physical properties of seawater for the next $50 \mathrm{yr}$.

Sørensen did make some dye-based measurements of seawater pH (Sørensen and Palitzsch, 1909) and this must have been in his mind from the classic work carried just a few years earlier. No significant survey was undertaken by him, but with his establishment of the $\mathrm{pH}$ scale it was not long before scientists throughout the world would examine this and probe the consequences and impacts of change.

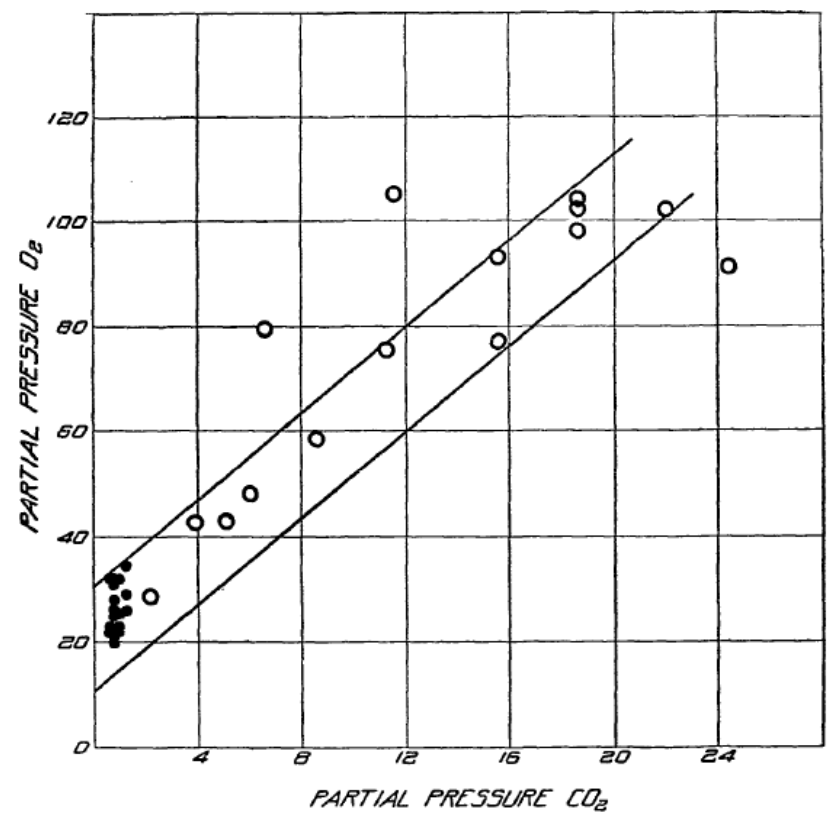

Fig. 2. From Redfield and Goodkind (1929). Partial pressures of oxygen and carbon dioxide (mm.Hg) lethal to the squid Loligo pealei. They found that the better the animal was oxygenated, the better it was able to withstand elevated $\mathrm{CO}_{2}$ levels. It was concluded that " $\mathrm{CO}_{2}$ exerts no toxic effect except through its influence on the oxygenation of the blood." Very similar conclusions are reached today. Although it is recognized that there is a vast range of tolerance of deep-sea animals to hypoxia and hypercapnia the concept of the $\mathrm{O}_{2}: \mathrm{CO}_{2}$ ratio very likely has relevance for regional impacts today.

\section{The first $50 \mathrm{yr}$}

Early inquiries into the influence of $\mathrm{pH}$ focused on biological systems, although techniques were still crude. Powers (1922) investigated "the ability of marine fishes to extract oxygen from seawater at different hydrogen ion concentrations", and did so by means of keeping fish in an air-tight Mason jar until they asphyxiated, at which time the $\mathrm{O}_{2}$ level was recorded. Several experiments at different $\mathrm{pH}$ were carried out. He concluded that "the ability of marine fishes to absorb oxygen at low tension from the seawater is more or less dependent upon the hydrogen ion concentration of the water."

A more important study was carried out by Redfield and Goodkind (1929) in their investigation of the correlated impacts of $\mathrm{O}_{2}$ and $\mathrm{CO}_{2}$ respiratory stress on the squid Loligo pealei as one of the earliest experiments on hemocyaninbased respiratory systems. They carried animals to the point of asphyxiation and found a strong correlation (Fig. 2), such that better oxygenated animals were able to withstand higher $\mathrm{CO}_{2}$ concentrations. They concluded that " $\mathrm{CO}_{2}$ exerts no toxic effect except through its influence on the oxygenation of the blood." Very similar conclusions are reached today, and when the IPCC reviewed (Caldeira et al., 2005) the issues 
surrounding $\mathrm{CO}_{2}$ capture and storage, the likely oceanic impacts were noted as "acute $\mathrm{CO}_{2}$ exposure causes acidification of the blood, will hamper oxygen uptake and binding at the gills and reduce the amount of oxygen carried in the blood, limiting performance and at high concentrations could cause death", thereby echoing the work carried out some $75 \mathrm{yr}$ earlier and foreshadowing the world of "multiple stressors" as ocean $\mathrm{CO}_{2}$ levels rise, and $\mathrm{O}_{2}$ levels at depth decline.

The earliest major survey of ocean $\mathrm{pH}$ was reported by Wattenberg (1933) from the results of the German Atlantic expedition of the "Meteor" 1925-1927, and ocean pH sections derived from colorimetric techniques were reported with $0.1 \mathrm{pH}$ resolution contours.

However it was not until 1938 that a major foray into $\mathrm{CO}_{2}$-induced climate change and ocean chemistry occurred (Callendar, 1938). Callendar was keenly aware of the earlier work by Arrhenius and others, but made a fully independent attack. He noted that "the effect of solution of the gas was next considered, because the sea acts as a giant regulator of carbon dioxide and holds some sixty times as much as the atmosphere." He necessarily invoked ocean alkalinity and with his prediction of future $\mathrm{pCO}_{2}$ he could have calculated the change in $\mathrm{pH}$ since the basic equations incorporating the $\mathrm{CO}_{2}-\mathrm{HCO}_{3}^{-}-\mathrm{CO}_{3}^{=}$and $\mathrm{B}\left(\mathrm{OH}_{4}\right)^{-}$terms were available.

$\mathrm{He}$ did make predictions of future atmospheric $\mathrm{CO}_{2} \mathrm{lev}-$ els, and global temperature rise assuming oceanic equilibrium times (full ventilation ages) of 2000 and $5000 \mathrm{yr}$. With only a slide rule as a computer he predicted a temperature rise of $2{ }^{\circ} \mathrm{C}$ from $\mathrm{CO}_{2}$ doubling with some $50 \%$ transfer of emitted $\mathrm{CO}_{2}$ to the ocean (Fig. 3) and mean surface $p \mathrm{CO}_{2}$ rising to $373 \mathrm{ppm}$. The temperature rise predicted is remarkably close to today's sophisticated computer models. But Callendar erred greatly in predicting the future rate of growth in $\mathrm{CO}_{2}$ emissions. He estimated an atmospheric $\mathrm{CO}_{2}$ level of $373 \mathrm{ppm}$ by the year 2200; we reached that value some 200 years earlier, at the end of the 20th century. The error of underestimating the speed of energy-dependent economic growth $\left(\mathrm{CO}_{2}\right.$ emissions) world wide is still played out today, for the 1990 IPCC Report on climate change significantly underestimated the emissions we see some $20 \mathrm{yr}$ later.

With the monumental publication of The Oceans in 1942 by Sverdrup et al., much ocean science information was synthesized for the first time. But the 1938 paper by Callendar was not cited, nor was modern climate change discussed.

\section{$3 \quad 1950-1980$}

With the end of World War II the nations needed time to heal. The creation of the 1957-1958 International Geophysical Year (IGY) provided a much needed rebirth of international geophysical science including ocean science, and importantly established a vehicle for scientific communication in the Cold War years.

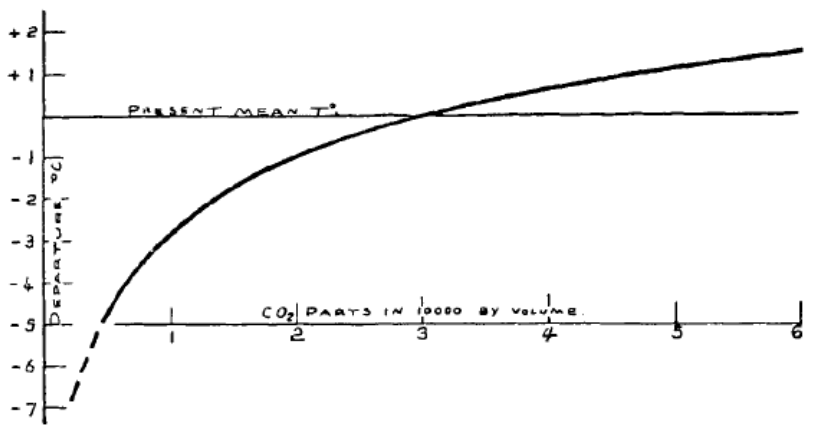

\begin{tabular}{|c|c|c|c|c|}
\hline Period & $1910-1930$ & 20th century & 21 st century & 22ad century \\
\hline $\begin{array}{l}\text { Mean } P\left(\mathrm{CO}_{a}\right) \\
\text { Mean } \Delta T .{ }^{\circ} . \\
\text { Pulat displacement ot } \\
\text { climate zones. }\end{array}$ & $\begin{array}{r}2.82 \\
+0.07^{\circ} \\
15\end{array}$ & $\begin{array}{r}2.92 \\
+0.16^{\circ} \\
36\end{array}$ & $\begin{array}{r}3.30 \\
+0.39^{\circ} \\
87\end{array}$ & $\begin{aligned} & 3.60 \\
+ & 0.57^{\circ} \\
& 127 \mathrm{~km} .\end{aligned}$ \\
\hline
\end{tabular}

Fig. 3. From Callendar (1938). Armed only with a slide rule as a calculating machine, Callendar produced a very credible estimate (upper panel) of the warming produced by $\mathrm{CO}_{2}$ doubling in the atmosphere. He assumed an ocean mixing time of $2000 \mathrm{yr}$ and viewed the ocean alkalinity as providing the key chemical capacity. But while Callendar had the robust physics of the radiation balance to rely on, his economic projections were less sound (lower panel). His estimate of atmospheric $\mathrm{CO}_{2}$ levels in the 22nd century was reached by the end of the 20th century. He noted that alkalinity was not changed, but did not mention $\mathrm{pH}$.

An impetus towards climate science and its relationship to the geochemical balance of the ocean and the Earth had been provided by Rubey (1951) in his superb address as retiring President of the Geological Society of America. Rubey was concerned with the balance between the opposing forces of emitted volcanic acids, and bases released from rock weathering, that have led to a habitable planet. He drew particular attention to "the significance of carbon dioxide in the atmosphere-ocean system" and noted that "carbon plays a significant part in the chemistry of seawater and in the realm of living matter. The amount now buried as carbonates and organic carbon in sedimentary rocks is about 600 times as great as that in today's atmosphere, hydrosphere, and biosphere. If only $1 / 100$ of this buried carbon were suddenly added to the present atmosphere and ocean, many species of marine organisms would probably be exterminated."

On geologic timescales our $\mathrm{CO}_{2}$ emissions today are clearly "sudden" and the rate of release exceeds by orders of magnitude any event in Earth's geologic past.

IGY planning included the need for atmospheric $\mathrm{CO}_{2}$ measurements, but not oceanic ones (Keeling, 1978). However, Revelle and Suess (1957) directly addressed the role of the ocean in absorbing fossil fuel $\mathrm{CO}_{2}$ and, by using radiocarbon-based estimates, suggested that some $40 \%$ of the emitted $\mathrm{CO}_{2}$ would be transferred quickly to the ocean. Revelle and Suess did not estimate $\mathrm{pH}$ changes, but could 
easily have done so. Their analysis was clearly prescient; they reported that "in the coming decades... a total increase of $20-40 \%$ in atmospheric $\mathrm{CO}_{2}$ can be anticipated. This should be adequate to determine ... effects on weather and climate." The IPCC identification of man-made climate change in 1990 occurred almost exactly at the $30 \%$ increase level predicted $33 \mathrm{yr}$ earlier. The 1957 paper by Revelle and Suess had an enormous and lasting impact. It stimulated a keen awareness of the need to quantify the role of the ocean in the planetary $\mathrm{CO}_{2}$ balance. One of the very earliest and classic analyses was provided by Bert Bolin. Bolin was an early contributor to the fundamental science of air-sea $\mathrm{CO}_{2}$ exchange and the flux enhancement associated with aqueous boundary layer $\mathrm{CO}_{2}$ chemistry (Bolin, 1960). The basic equations developed by Bolin in 1960 are directly applicable to $\mathrm{CO}_{2}$ boundary processes and exchange rates between the ocean and marine animals today.

This was a formative time for the ocean sciences. The first International Oceanographic Congress was held at the UN in New York in 1959, with the opening address given by Revelle. The collected papers from this Congress are remarkable (Sears, 1961), with the first quantitative analysis of the physical chemistry of seawater (Sillén, 1961). Sillén did not cite the earlier paper by Rubey (1951) but tackled the same subject matter in a more rigorous manner. He asked "What makes the pH equal 8.2?" and viewed the ocean as "the result of a gigantic acid-base titration: acids that leaked out from the interior of the Earth, $\mathrm{HCl}, \mathrm{H}_{2} \mathrm{SO}_{4}, \mathrm{CO}_{2}$, are titrated with bases that have been set free by the weathering of primary rock," and found that we are within about $0.5 \%$ of the planetary equivalence point and thus that "the $\mathrm{pH}$ of the ocean is somewhat precarious." He found the primary long-term buffer not to be the oceanic $\mathrm{CO}_{2}$ system, but the weathering of silicate rocks. Some $50 \mathrm{yr}$ later we observe this to be true: we are rapidly changing the "precarious" ocean $\mathrm{pH}$ and the somewhat fragile oceanic $\mathrm{CO}_{2}$ system - and planetary recovery will depend upon the slow rate of silicate rock weathering with a timescale of $\sim 1$ million years (Zeebe and Ridgwell, 2011).

While US and European ocean scientists were slow to build capable ocean $\mathrm{CO}_{2}$ measurement systems, Soviet scientists ploughed ahead. In a remarkable but little-noticed effort in the 1960s, scientists allied to the Soviet Navy carried out a world-wide survey of the major ocean basins (Gorshkov, 1978), and included pH measurements (Fig. 4) graphed in $0.1 \mathrm{pH}$ intervals. These measurements were likely made using an early form of the buffers which were already forming the basis of what later became the fully developed and widely used NBS scale.

Those who saw the measurement systems first-hand during port visits could not fail to notice the very large reference electrode $\mathrm{KCl}$ reservoirs required by the unusually high flow rate through the electrode liquid junction, and the need to read a sensitive galvanometer needle on a heaving and rolling ship. This does not negate the data, and inspection of the Gor-
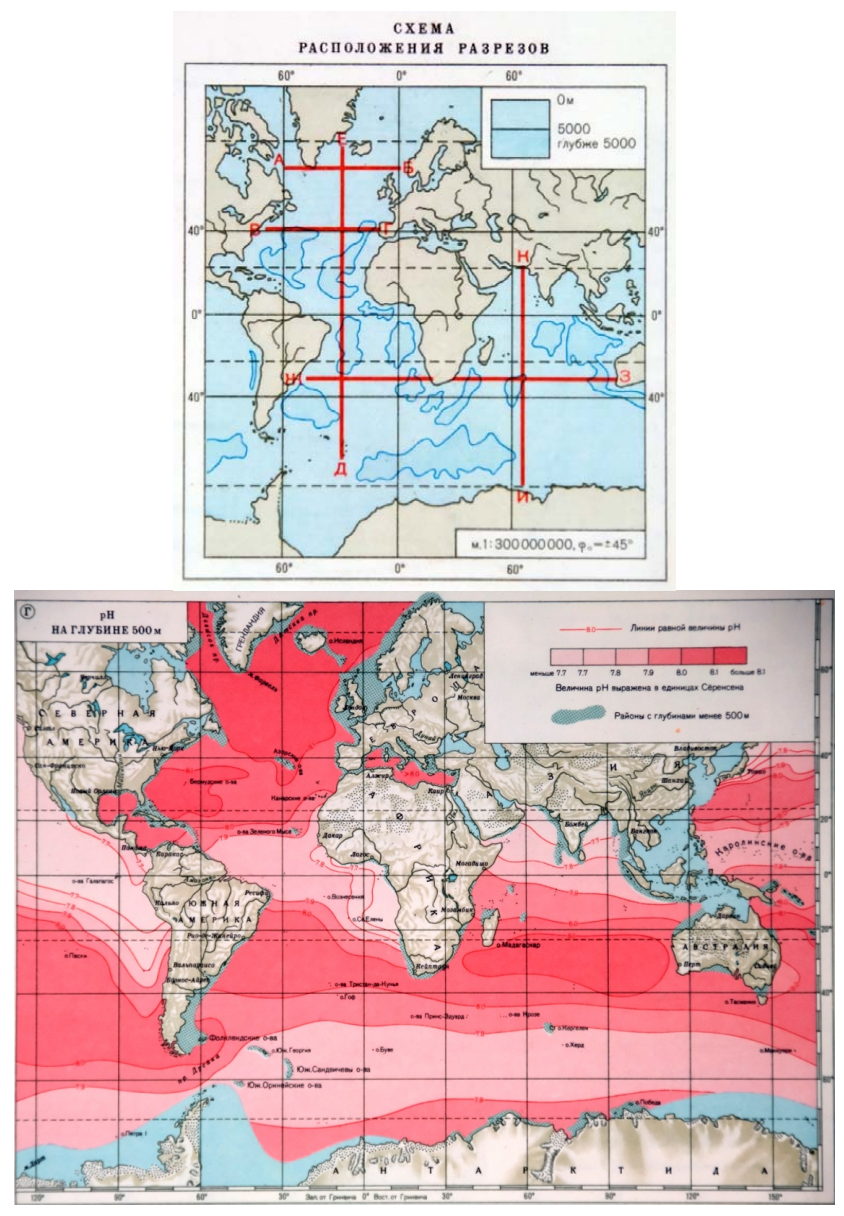

Fig. 4. From Gorshkov (1978). The ocean pH survey grid carried out by Soviet scientists in the 1960s (upper panel), and a map of the $500 \mathrm{~m}$ depth $\mathrm{pH}$ field reported (lower panel). The results were contoured in $0.1 \mathrm{pH}$ intervals. US Navy scientists later plotted these data, interpolated the curve, and remarkably then reported the results to $\pm \mathrm{pH}$ units. This was one of the first snapshots of the large scale ocean $\mathrm{pH}$ field.

shkov Atlas data strongly suggests that this data set may be a valuable but under-utilized resource for ocean geochemists. The data were heavily used, and optimistically interpolated so as to infer a full order of magnitude increase in precision (!) by US Navy scientists in the prediction of the anomalous oceanic $1 \mathrm{kHz}$ acoustic absorption phenomenon (Francois and Garrison, 1978) - remarkable testimony to the relative absence of reliable US ocean data in this time period.

The tradition of using single point direct electrode $\mathrm{pH}$ measurements had by this time become suspect. A major innovation was the establishment of an elegant and precise full titrimetric procedure, first executed at sea aboard the small research vessel Sagitta at a station in the archipelago off Gothenburg (Dyrssen, 1965) and soon thereafter expanded (Dyrssen and Sillén, 1967) with the introduction of solution equilibrium concepts and the exact establishment of the 

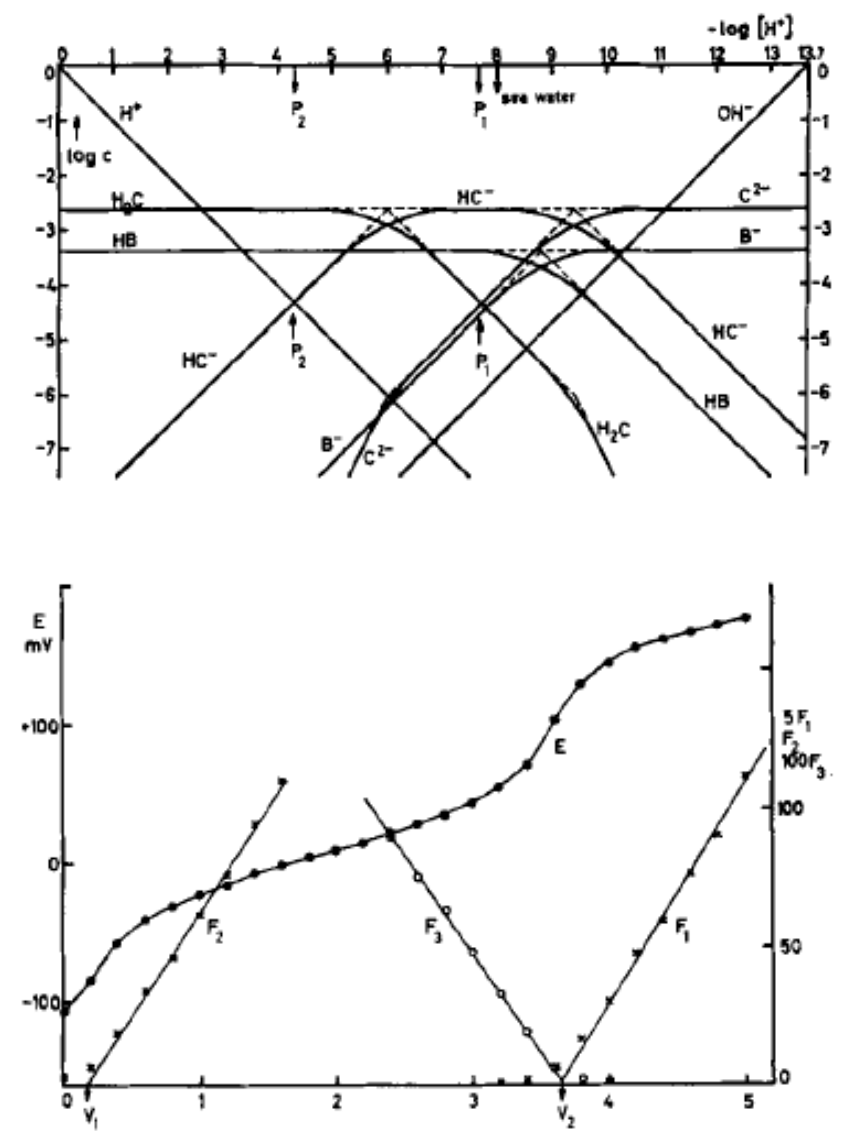

Fig. 5. From Dyrssen and Sillen (1967). Upper panel: a Bjerrum chemical equilibrium plot of the major seawater species involved in protonation as acid is progressively added to seawater in a titration. Lower panel: the recommended "gran plot" treatment of the titration data so as to provide linear functions for determination of the equivalence points, and a measure of both alkalinity and total $\mathrm{CO}_{2}$. This procedure and its descendants were used thousands of times during the Geosecs global survey in the 1970s.

equivalence point of the chemical reactions (Fig. 5). This technique soon became adopted with only minor modification in the US (Edmond, 1970).

By the late 1960s the lack of a well-founded ocean $\mathrm{CO}_{2}$ chemistry capability in the US had become clear. Serious discussions arose in 1967 regarding the need for a global survey of the ocean $\mathrm{CO}_{2}$ properties, including radiocarbon, and this evolved into the Geosecs program. One early effort was the execution of a 1969 "test station" (Turekian, 1970): this was a debacle. Here the combined efforts of 8 scientists to measure all 4 of the oceanic $\mathrm{CO}_{2}$ system properties ( $\mathrm{pH}, p \mathrm{CO}_{2}$, alkalinity, and $t \mathrm{CO}_{2}$ ) at a single station and to link these by use of the thermodynamic constants so as to close the loop and verify accuracy (Takahashi et al., 1970) was severely tested (Fig. 6). The errors found far exceeded the design goals of constraining the radiocarbon measurements. Direct detection of the oceanic fossil fuel $\mathrm{CO}_{2}$ signal was not on the horizon

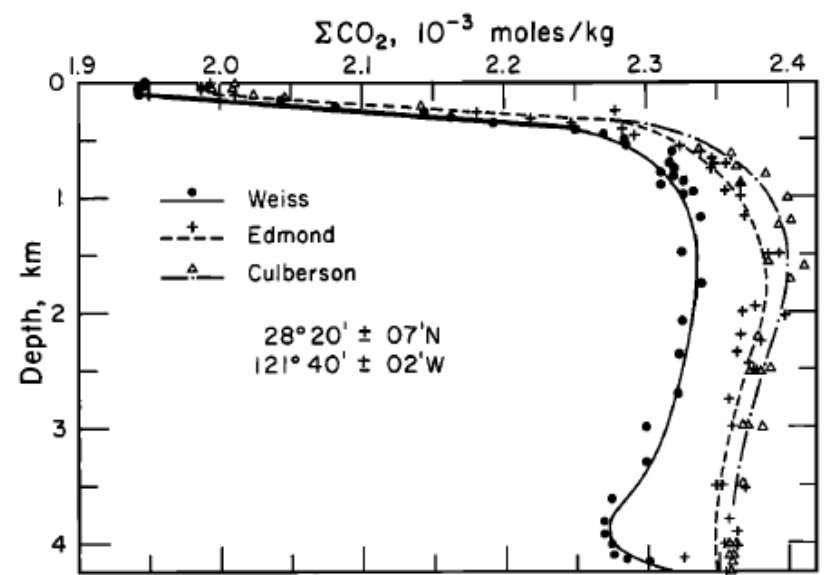

Total Alkalinity, milli-equiv. $/ \mathrm{kg}$

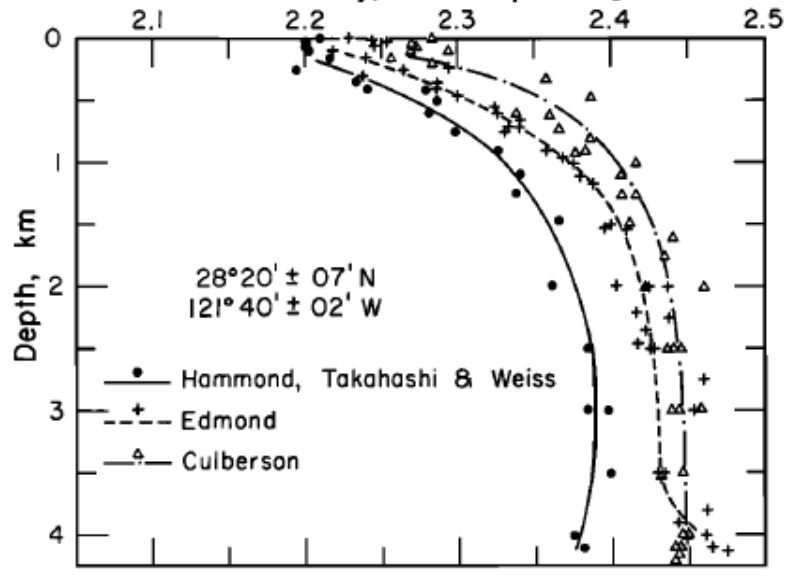

Fig. 6. From Takahashi et al. (1970). Results of various laboratory teams on measurements of seawater total $\mathrm{CO}_{2}$ (upper panel) and total alkalinity (lower panel) at the 1969 Geosecs test station offshore San Diego, California. The $t \mathrm{CO}_{2}$ comparison is of results obtained by gas chromatography (solid circles), titration ( + marks) and a combination of $\mathrm{pH}$ and alkalinity ( $\Delta$ sign). The discrepancies of between 3 and $5 \%$ in $t \mathrm{CO}_{2}$ (over 70 micromoles per $\mathrm{kg}$ ) were cause for concern. Data obtained today are typically better by about a factor of 30 .

given this performance. A detailed account of the exhaustive tracking down of errors and re-writing of the fundamental ocean acidification equations as titration steps occur was later given (Bradshaw et al., 1981); it was no trivial task.

Nonetheless the Geosecs program proceeded with major surveys of the Atlantic (1972), the Pacific (1974), and the Indian Ocean (1978). Errors in the accumulated $\mathrm{CO}_{2}$ system observations, revealed by comparing measured $p \mathrm{CO}_{2}$ versus $p \mathrm{CO}_{2}$ computed from the alkalinity- $t \mathrm{CO}_{2}$ pair, persisted until the 1981 publication of the revision of the fundamental titrimetric equations and reanalysis of the entire expeditionary titration data set.

While the at-sea Geosecs juggernaut was proceeding, important steps in $\mathrm{CO}_{2}$ system interpretation and signal 


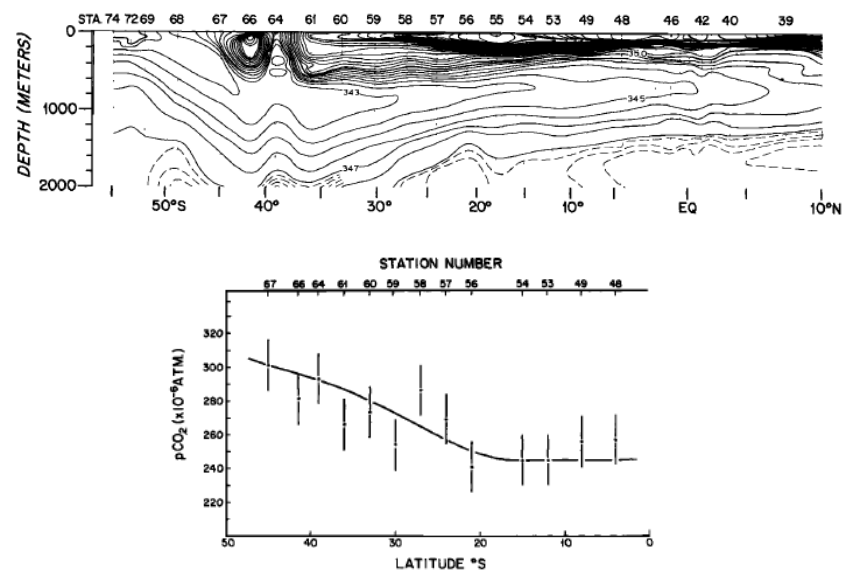

Fig. 7. From Brewer (1978). The first attempt at recovering the fossil fuel $\mathrm{CO}_{2}$ signal by direct measurement of water masses. The data were obtained during the Geosecs Atlantic cruise in 1972. Upper panel: a section through the well-defined salinity minimum of the Antarctic intermediate water. Lower panel: the estimated original $p \mathrm{CO}_{2}$ of the water mass after correction for sub-surface changes in $t \mathrm{CO}_{2}$ from respiration, and alkalinity changes from carbonate dissolution and nitrate regeneration. The trend in initial $p \mathrm{CO}_{2}$ from the recent (far left) to older (far right) waters closely follows the known 20th century trend.

detection were occurring, driven significantly by the urge to deal with the large expedition investment. These efforts were not without controversy, but were to lead directly to the ability to recover the oceanic fossil fuel $\mathrm{CO}_{2}$ signal above the large, complex natural background and thus to ocean acidification science as the perturbation phenomenon became ever more readily recognizable.

In the early 1970s questions over the long-term impact of the accumulation of fossil fuel $\mathrm{CO}_{2}$ in the sea were already arising around the world and causing strong debate. Fairhall (1973) commented on the accumulation of fossil $\mathrm{CO}_{2}$ in the atmosphere and sea and drew attention to the possible impacts on marine life. This concern was quickly responded to by Whitfield (1974) who remarked that "An analysis from the chemist's point of view of the uptake of industrial produced carbon dioxide by the oceans reveals that serious environmental effects are not likely in the foreseeable future." The vigor of the response and the professional complexity in dealing with the oceanic $\mathrm{CO}_{2}$ system was a harbinger of debates to come.

The events leading to direct recognition of the oceanic fossil fuel $\mathrm{CO}_{2}$ imprint occurred quickly and were subjected to fierce debate. In a publication of a high-accuracy ocean $\mathrm{Ca}$ profile (Horibe et al., 1974) an anomalous interpretation of alkalinity was given. Brewer et al. (1975) pointed out that there was no anomaly if the strong acid effect of release of $\mathrm{NO}_{3}^{-}$from microbial oxidation of organic matter is considered, thus consuming alkalinity as spelled out in the classic Redfield equation (Redfield, 1934). This aroused controversy (even ridicule), for the proton balance inherent in the Redfield equation had not earlier been taken literally. The reality of this was experimentally demonstrated in a series of phytoplankton growth experiments on both $\mathrm{NO}_{3}$ and $\mathrm{NH}_{4}$ nutrient sources, with the alkalinity changes being directly observed (Brewer and Goldman, 1976; Goldman and Brewer, 1980).

With the new ability to reconcile the observed oceanic alkalinity profiles it became possible to attempt recover the oceanic fossil fuel $\mathrm{CO}_{2}$ signal now overlaid on the very large and complex natural oceanic $\mathrm{CO}_{2}$ background. The results of the Geosecs survey, in spite of obvious but temporary flaws, were the natural vehicle for this. This was first demonstrated by Brewer (1978) using the tactic of stripping out the changes due to production of respiratory $\mathrm{CO}_{2}$ via the equivalent observed loss of $\mathrm{O}_{2}$, and by correcting for the alkalinity changes due to $\mathrm{CaCO}_{3}$ dissolution and $\mathrm{NO}_{3}$ production. From the corrected values a clear trend was found within the Antarctic Intermediate Water mass from initial low, pre-industrial, $p \mathrm{CO}_{2}$ in the interior to higher contemporary values close to the source (Fig. 7). A similar approach, but using the metric of the total $\mathrm{CO}_{2}$ anomaly, was soon independently published by Chen and Millero (1979). This approach was accepted by many, but strongly critiqued by some (Broecker et al., 1985), principally for the uncertainty over the boundary conditions. Nonetheless this basic formalism of reliance on the venerable Redfield equations and the then newly established $\mathrm{NO}_{3}$ correction of alkalinity remains the basis for virtually all of the procedures for recovery of the oceanic fossil fuel signal profiles today (Sabine et al., 2004).

The debate over Earth controls on the steadily increasing fossil fuel signal in the atmosphere and the role played by the ocean attracted the attention of scientific administrators, who sought to allocate funds in the best way, and a major meeting was convened in 1976 to address this (Andersen and Malahoff, 1977). The dominant focus of this meeting and the 36 papers presented was the role played by oceanic carbonate sediments in future neutralization of the increasing oceanic $\mathrm{CO}_{2}$ load.

Oddly there was no discussion at that time of direct impacts on marine life or on coral reefs. But attention was given to what later became a critical debate - the relative importance of the land biosphere versus oceanic uptake. In a remarkably candid account Lemon (1977) addressed the matter of future $\mathrm{CO}_{2}$ "fertilization" of land vegetation. He noted, "Let me give an extreme example. For some time greenhouse men have been adding $\mathrm{CO}_{2}$ in their closed system to increase yields, say of tomatoes, lettuce, cucumbers and carnations. (By yield in this sense I mean marketable product, not necessarily carbon accumulation.) This distinction is important. The Dutch have found that more $\mathrm{CO}_{2}$ in a glasshouse gives an earlier and bigger crop of fresh lettuce, yet on a dry matter basis (accumulated carbon) there is no difference between a $\mathrm{CO}_{2}$ fertilized crop and a non-fertilized one. The canny Dutchmen are selling more water to the housewife packaged in green leaves. I stress this extreme case to pinpoint 
the complexity of forecasting what land plants will do with added $\mathrm{CO}_{2}$."

The effects of added $\mathrm{CO}_{2}$ to the open atmosphere surrounding all forms of terrestrial vegetation were later explored in a large series of FACE (Free Air $\mathrm{CO}_{2}$ Enrichment) experiments, and a null result was indeed found with the pithy headline in Science "Plant productivity benefits of high carbon dioxide busted" in comment on the paper by Long et al. (2006), thus supporting the rather sad prediction made some $30 \mathrm{yr}$ earlier. Similar field experiments on oceanic systems are only now being attempted.

By 1977 scientific interest world-wide had arisen over climate change and conjectures over how to tackle this in some practical way were emerging. Marchetti (1977) first proposed direct ocean $\mathrm{CO}_{2}$ disposal by capture of fossil fuel $\mathrm{CO}_{2}$ at the point of combustion, and injection via pipeline under the Mediterranean outflow. He saw the matter as a problem of rate of transfer from the air to the ocean - if the $\mathrm{CO}_{2}$ could be disposed of in the ocean where the vast majority would in any case end up - then the climate problem of $\mathrm{CO}_{2}$ in the atmosphere would be greatly reduced. He did not consider chemical or biological consequences for the ocean.

Students of this era may wonder why such a simple statement such as "ocean $\mathrm{pH}$ is changing as a result of fossil fuel $\mathrm{CO}_{2}$ invasion" was so carefully avoided, when the steady stream of information on changing $p \mathrm{CO}_{2}$ and $t \mathrm{CO}_{2}$ all pointed very directly to this. It was because that information was so self-evident that it need not be stated in those terms, but also because of the strong influence of David Keeling. Keeling was a giant in this field, and had worked hard as a young man to reject the idea that direct $\mathrm{pH}$ measurements of seawater were useful as compared to high-quality direct measurements of $t \mathrm{CO}_{2}$ (Keeling, 1968; Keeling and Bolin, 1967, 1968). His comments are revealing: "from the time of the expeditions of the Discovery [Deacon, 1940] until the International Geophysical Year, 1957-1958, almost all investigators of the carbon system in ocean water relied on $\mathrm{pH}$ measurements to determine $p \mathrm{CO}_{2}$. These investigators, in their optimism for having found a simple measuring routine, failed to note that the new method was scarcely capable of detecting the small changes in $\mathrm{pH}$ of surface ocean water that reflect significant changes in $p \mathrm{CO}_{2}$. Furthermore, "the complicated electrochemical property, $\mathrm{pH}, \ldots$ and quotients of chemical concentrations such as "specific" alkalinity ... are therefore unacceptable as tracers." His comments resonated, his concern was well founded, and use of $\mathrm{pH}$ as a reliable metric was carefully avoided for decades.

\section{$4 \quad 1980-1990$}

This decade saw the remarkable transition from climate/ocean change science being the scholarly pursuit of a dedicated few at the start of the decade, to a huge matter of public and international policy at the end. The pri- mary political force for this in the US was supplied by Al Gore (later to become only the second person in the world to be awarded both a Nobel Prize and an Oscar; the first was George Bernard Shaw). In Europe the science-policy charge was led by Bert Bolin whose legacy is remarkable but who was sadly afforded much less public recognition. In the US the definitive policy event occurred with the 1989 publication of "Our Changing Planet: A US Strategy for Global Change Research" (an insiders account of this is given by Bromley 1994); and a world-wide transition occurred in 1990 with the publication of the first IPCC Scientific Assessment (Houghton et al., 1990). Ocean scientists played a significant role in this development, although recognition of the likely $\mathrm{CO}_{2} /$ climate impacts on marine life was slow in coming and did not receive proper recognition until more than a decade later.

With the 1981 publication of a full-fledged chemical model of seawater buffering against acidic change (Bradshaw et al., 1981) and the initiation of oceanic fossil fuel $\mathrm{CO}_{2}$ signal recovery (Brewer, 1978; Chen and Millero, 1979), it became possible to move beyond the largely abiological Geosecs tracer approach and consider a full-scale attack on the complexities of the ocean carbon cycle and the biogeochemical fluxes that maintain it. The topic was first addressed in an oblique way at a NATO workshop held in Jouy-enJosas, France, initiated by Roger Chesselet (Burton et al., 1986). Two papers at that meeting helped John Steele formulate the ideas which led to the JGOFS (Joint Global Ocean Flux) program which was to combine ocean organic carbon fluxes with the changing $\mathrm{CO}_{2}$ chemistry of the ocean: Bruland and Coale (1986) showed the power of ${ }^{234} \mathrm{Th}$ scavenging observations as a determinant of upper ocean particle fluxes to the deep sea and Brewer (1986) showed that within the seasonal cycles of ocean $\mathrm{CO}_{2}$ now being observed, both physical and biological processes were at work and could be distinguished and separated.

The ocean observing follow-on to the large Geosecs program of the 1970s began as the TTO (Transient Tracers in the Ocean) program (see Broecker and Peng, 1982 for a detailed background) but the focus here was on the physical and isotopic distribution of oceanic chemical species as a guide to integrative physical circulation processes; significant Atlantic expeditions in 1981 and 1983 were carried out (Brewer et al., 1985) and the first accurate basin-scale survey of the oceanic $\mathrm{CO}_{2}$ properties was mapped.

The critical matter of competence and ability to address the primary ocean biogeochemical cycles now loomed large. A report entitled "Changing Climate" was produced by the US National Academy of Sciences and the role of ocean chemistry as an essential $\mathrm{CO}_{2} /$ climate mediator was addressed (Brewer, 1983). The funding for climate change science had grown with the glimmer of the future US Global Change Research Program emerging and two major ocean thrusts were developed. One was the initiation of the WOCE (the International World Ocean Circulation program) 
program led by Carl Wunsch; the second was the 1984/1985 development of the US GOFS (Global Ocean Fluxes) program led first by John Steele, which in 1987 became the fully international JGOFS (Joint Global Ocean Fluxes) program chaired by Bernd Schneider. A detailed account of the founding (Brewer, 2003) is given in the Foreword to the important 2003 text on "Ocean Biogeochemistry" (Fasham, 2003) in which much of the knowledge gained from the JGOFS program is summarized. It was the combination of the detailed work on processes and time series within JGOFS, and the addition of a high-quality $\mathrm{CO}_{2}$ measurement program to the WOCE global hydrographic survey that proved to be powerful.

There was initially much resistance to the idea of adding a major ocean $\mathrm{CO}_{2}$ observing capability to the WOCE hydrographic survey. There were doubts in the ocean physics community as to the value of the data, and skepticism as to the ability of the technical teams to achieve and maintain data of the desired quality and consistence over thousands of measurements over many years. The agreement to partner on this as a joint project between the JGOFS and WOCE programs was eventually sealed by a handshake agreement at a US National Academy of Sciences meeting, and then rapidly communicated to SCOR (the Scientific Committee on Oceanic Research) for international ratification.

The coordinated large-scale ocean observing programs initiated in the 1980s could not have succeeded without strong technical breakthroughs in ocean $\mathrm{CO}_{2}$ observations resulting in increases in both accuracy and precision. The elegant high-precision titrimetric determination of alkalinity first demonstrated by Dyrssen and Sillén (1967) proved difficult for the associated accurate determination of $t \mathrm{CO}_{2}$ and for this it was replaced by the coulometric technique of Johnson et al. (1985) which enhanced precision and accuracy by a factor of 4 . The glass electrode measurement of $\mathrm{pH}$, so troublesome, was elegantly replaced by the high-precision spectrophotometric techniques developed by Byrne and colleagues culminating with (Byrne and Breland, 1989) a precision at sea of $\pm 0.001 \mathrm{pH}$ units.

Armed with these two techniques, and combining with the full arsenal of isotopic methods, etc., for tackling ocean productivity and the fate of the organic matter produced, ocean scientists initiated a combined attack on the changing ocean $\mathrm{CO}_{2}$ status and its climatic response. Time series stations at Bermuda and Hawaii were begun, a whole series of sophisticated process study cruises were executed in the major ocean regions, and a global survey of the ocean $\mathrm{CO}_{2}$ system properties was carried out in a unique combination of the JGOFS and WOCE programs. This effort was brought to fruition at the close of the decade with the 1989 North Atlantic Bloom Experiment in which US, German, UK, Canadian and Dutch ships, aircraft, and scientists all participated.

The time series effort continues to this day and, as previously promised, has delivered with remarkable clarity definitive evidence of rapidly changing ocean acidification (Dore et al., 2009). Today the availability of painstakingly developed standard reference materials (Dickson et al., 2003) assures the unimpeachable quality of the data obtained.

\section{$5 \quad 1990-2000$}

This period saw completed the vast majority of the hard work at sea of the JGOFS and WOCE programs by truly dedicated scientists. These data deserve enormous respect for the sustained quality of the human endeavor to quantify the biogeochemical science of the ocean and reveal its sensitivity to change. These efforts provided the basis for the global data sets so widely used today. The decade also saw the remarkable transition from the view of ocean $\mathrm{CO}_{2}$ uptake as an unmitigated blessing, to emerging concern as the full scale of the impacts began to be apparent. It was in retrospect a turbulent time, as the sometimes fierce debate proceeded and critical thresholds were crossed.

\subsection{The initial IPCC reports}

This decade began with the 1990 publication of the first IPCC Working Group 1 Scientific Assessment (Houghton et al., 1990), which produced a sea change in scientific, policy, and public thinking. The IPCC chapter teams had been working diligently for the later years of the 1980s and for the first time a seemingly authoritative projection of future $\mathrm{CO}_{2}$ emission scenarios was produced. The most prominent of these projections was the "business as usual" scenario, which envisioned a year 2100 atmospheric $\mathrm{CO}_{2}$ level of about $850 \mathrm{ppm}$. But the 1990 IPCC report section 10.4 on "Marine Ecosystems and Climate Change" (Melillo et al., 1990) made no mention of ocean $\mathrm{pH}$ changes. It did have an extended review of $\mathrm{CO}_{2}$ interactions with land biota.

The 1995 Second Assessment Report of Working Group 1 (Houghton et al., 1996) did have a specific section 10 on "Marine Biotic Responses to Environmental Change and Feedbacks to Climate", but ocean acidification was not mentioned here, although the earlier scenarios of a high- $\mathrm{CO}_{2}$ world were reinforced.

These projections aroused concern across a wide spectrum of ocean geoscientists. Quite simple calculations showed that by the year 2100 typical surface ocean water $\mathrm{pH}$ would decline by an astonishing $0.4 \mathrm{pH}$ units, and carbonate ion by about $55 \%$ (Brewer, 1997) thus eerily verifying the "precarious" pH poise noted by Sillén in 1961. This projection of changing chemistry was initially ignored.

\subsection{The direct ocean $\mathrm{CO}_{2}$ disposal debate}

Exactly contemporaneous with the publication of the Brewer (1997) paper illuminating the ocean impact of "business as usual" came the issuance of a major US Government report to the Clinton/Gore administration containing recommendations for US energy policy (PCAST, 1997). That re- 


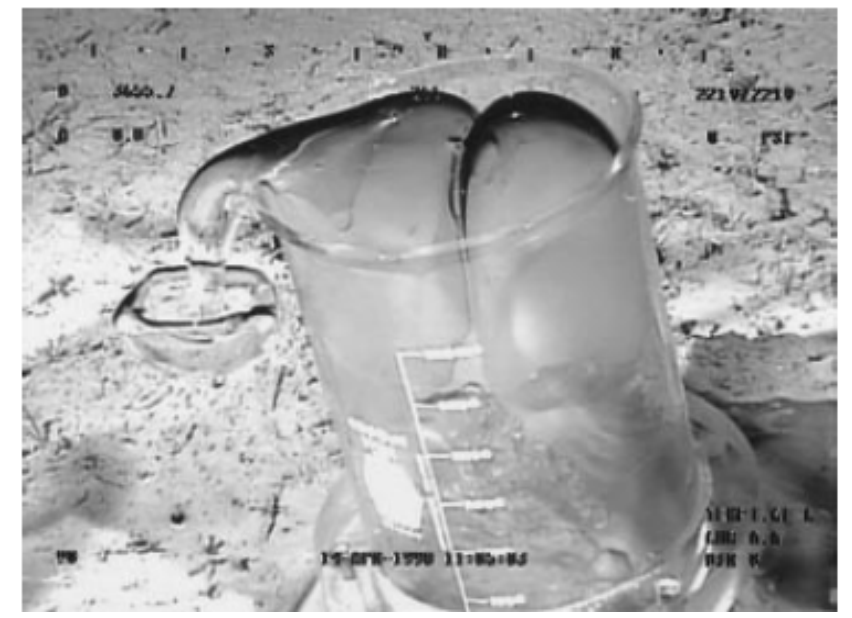

Fig. 8. From Brewer et al. (1999). An experiment in deep ocean fossil fuel $\mathrm{CO}_{2}$ disposal. A $4 \mathrm{~L}$ laboratory beaker was placed on the sea floor at $3.650 \mathrm{~m}$ depth and about $2 \mathrm{~L}$ of liquid $\mathrm{CO}_{2}$ dispensed into it to observe hydrate formation effects and test theory. $\mathrm{A} \mathrm{CO}_{2}$ hydrate "ice storm" occurred at the interface and slush of solids accumulated at the bottom, pushing excess liquid out of the top. A large fish and other deep-sea animals came by. This image captured significant attention and also aroused latent concerns.

port recommended a carbon sequestration program, with disposal of $\mathrm{CO}_{2}$ on the sea floor in the form of a solid hydrate as one significant option. In fact direct disposal of $\mathrm{CO}_{2}$ in the ocean had been advocated as a climate solution 30 years earlier by Marchetti (1977) and had already generated strong interest, particularly in Japan (Handa and Ohsumi, 1995).

Bewildered by the tepid reaction to the projection of massive losses of carbonate ion, and faced with such a strong recommendation for direct ocean disposal by the respected US PCAST group, a small team at the Monterey Bay Aquarium Research Institute (MBARI) chose to test this idea (Brewer et al., 1999). In a bold experiment carried out in April 1998 about $2 \mathrm{~L}$ of liquid $\mathrm{CO}_{2}$ was dispensed into a laboratory beaker placed on the sea floor at a depth of $3.650 \mathrm{~m}$ (Fig. 8) by using a remotely controlled vehicle.

Public reaction to this experiment was interesting, ranging from "You mean there are fish down there?" to "My God, you could change the $\mathrm{pH}$ of the ocean!" Apparently an image is indeed worth a thousand words. This was a very small but carefully planned experiment on a modest budget. A much bigger experiment had been planned by an international team for some time but had not been successful in securing the required permits. A good account of the debate is provided in Haugan (2003).

In fact the concept advanced in the 1997 PCAST report, that once a solid $\mathrm{CO}_{2}$ hydrate was formed on the sea floor it would be stable, was soon shown to be flawed. In later work by Rehder et al. (2004) it was demonstrated that hydrates of both methane and $\mathrm{CO}_{2}$ exposed on the sea floor quickly dissolved in the under-saturated seawater.
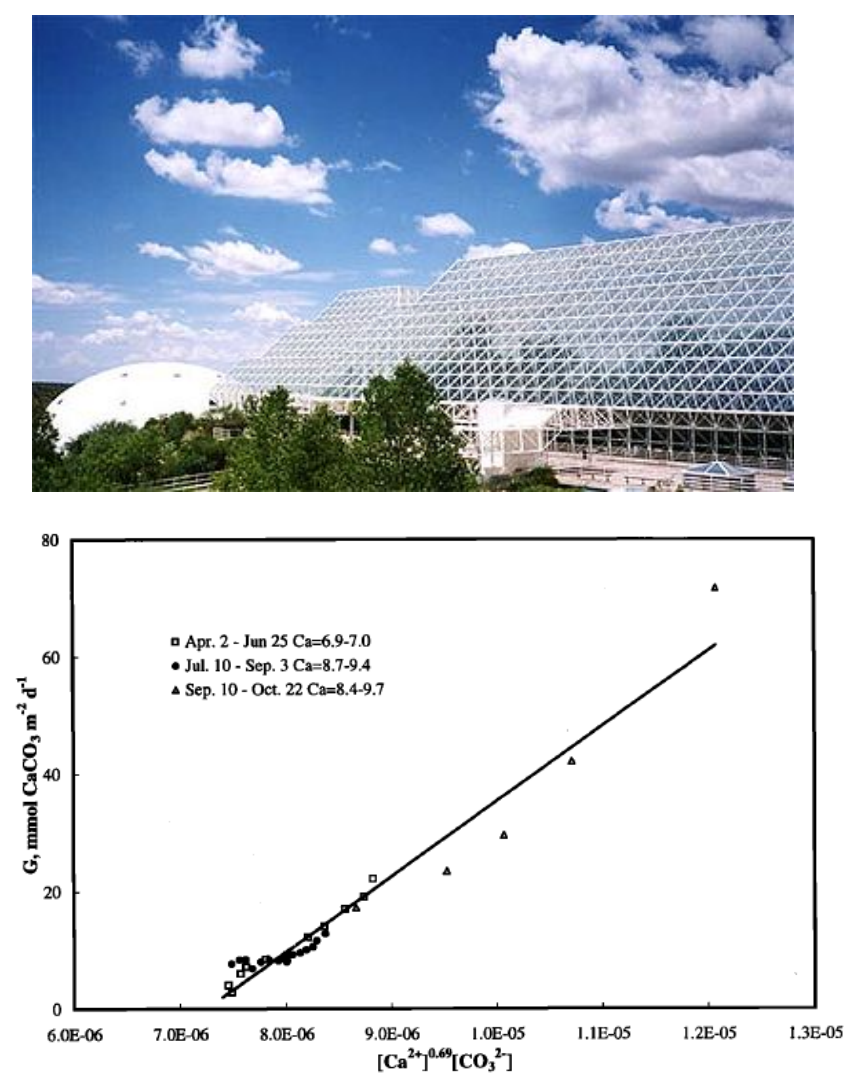

Fig. 9. The Biosphere 2 giant mesocosm unit in which the first experimental tests of the impact of high $\mathrm{CO}_{2}$ levels on calcification in marine corals was made (Langdon et al., 2000). Their data (lower panel) showed a strong relationship between the ion product of calcium carbonate (aragonite) and calcification rate, leading to a prediction of "a decrease in coral reef calcification between the years 1880 and 2065 ... of $40 \%$ ".

In 2002 the IPCC began the process of producing a Special Report on Carbon Dioxide Capture and Storage under the auspices of Working Group III, including a careful evaluation of ocean disposal and storage with associated biological and chemical impacts (Caldeira et al., 2005).

\subsection{The coral reef impact awakening}

By the mid-1990s, the likely impact of $\mathrm{CO}_{2}$ levels rising so high with the inevitable changes in $\mathrm{pH}$ and carbonate ion became a concern of scientists studying the fate of coral reefs. In the mid-1990s the primary debate was as to whether coral reefs, with their simultaneous mix of carbonate accumulation and organic primary productivity, would serve as a sink (productivity dominant) or a source (carbonate removal, increased $p \mathrm{CO}_{2}$ ) for atmospheric $\mathrm{CO}_{2}$ (Gattuso et al., 1996); the prevailing view was that they would typically represent a source (Gattuso et al., 1999).

But as the awareness of the chemical impact of the IPCC projections grew very serious concerns over future 
calcification rates were expressed and investigated. Kleypas et al. (1999) provided an authoritative overview of the recent experimental work and model projections. Data compiled in a major review of coralline species sensitivity to the $\mathrm{CO}_{2}$ status of the ocean (Gattuso et al., 1999) showed that coralline calcification rates were severely impacted by declining ocean carbonate ion levels.

Importantly the first major mesocosm of experimental results of the impacts of high $\mathrm{CO}_{2}$ levels on calcification rates (Fig. 9) was reported by Langdon et al. (2000) with the disturbing conclusion that "a decrease in coral reef calcification between the years 1880 and $2065 \ldots$ of $40 \%$ " was likely to occur.

Far more detailed projections of ocean chemical changes and the saturation state of aragonite were made by Kleypas et al. (2001) with the HAMOCC (Hamburg Ocean Carbon Cycle) model. These led to the disturbing conclusion that "Total preindustrial to 2100 calcification decrease could be as high as $17 \%$ to $35 \%$." A host of later papers and reviews have shown these original conclusions to be broadly correct.

\subsection{The phytoplankton connection}

While coral reefs are visible and greatly treasured by humans, the dominant calcification process in the ocean is by phytoplankton. By the end of the 20th century concerns over the future of calcareous phytoplankton in the face of changing ocean $\mathrm{pH}$ arose (Riebesell et al., 2000). Broader concerns and questions over $\mathrm{CO}_{2}$ impacts arose too on the fundamental photosynthetic process (Wolf-Gladrow et al., 1999). Furthermore, with the progress of the 21st century this has emerged as a powerful field for exploration with enormous complexity intermingled with the changing stratification of the ocean.

\section{Conclusions}

This review is an attempt to chart the course of chemical knowledge of the ocean and its changing $\mathrm{CO}_{2}$ status throughout the 20th century with sufficient rigor that the emerging fossil fuel signal could be revealed, and that awareness of both the climate benefits and the biogeochemical impacts could be made plain. The story has proceeded slowly due to the challenges involved, the complexity of the processes at work, and the relatively small size (in the early years) of the fossil fuel $\mathrm{CO}_{2}$ signal imposed on a large, geographically, and seasonally varying natural background.

By the end of the 20th century and by the seminal first "High $\mathrm{CO}_{2}$ Ocean" meeting in 2004 (Cicerone et al., 2004) a far busier scene had evolved. As the major IPCC Special Report on Carbon Capture and Storage was proceeding, greatly increased awareness of the impacts of what is now known as "Ocean Acidification" was increasing. Objectively the fears over direct ocean $\mathrm{CO}_{2}$ disposal are unwarranted; it would be too expensive, too controversial, and technically challenging to transfer large quantities of $\mathrm{CO}_{2}$ to great depth. But in any case such efforts would be dwarfed by the approximately 1 million tons of fossil fuel $\mathrm{CO}_{2}$ per hour now being transferred from air to sea; it is very doubtful that even 1 per cent of this quantity (10000 tons per hour) could be achieved by ships and pipelines. The "greater than $99 \%$ problem" and the associated climate benefit - is the net air to sea flux. Nonetheless, urgent discussions surrounding the concept of direct ocean $\mathrm{CO}_{2}$ disposal greatly aided the modern scientific understanding of the impacts of elevated $\mathrm{CO}_{2}$ on the ocean (Shirayama and Kogure, 2004).

Today the enormous increase in both experiments and models, and the vastly greater engagement of biologists in a field that was dominated by chemical efforts for almost $100 \mathrm{yr}$, is impressive. Impressive too is the realization that the not just the quantity but the rate of change will exceed that in the known geologic past (Caldeira and Wickett, 2003). However it is not 20th century history which is the focus here - it is the emerging tide of current events.

Acknowledgements. This work was supported by a grant to the Monterey Bay Aquarium Research Institute by the David and Lucile Packard Foundation. I thank Leif Anderson and Andrew Dickson for their meticulous, scholarly, and helpful reviews.

Edited by: H.-O. Pörtner

\section{References}

Andersen, N. R. and Malahoff, A.: The Fate of Fossil Fuel $\mathrm{CO}_{2}$ in the Oceans, Plenum Press, 749 pp. 1977

Bolin, B.: On the exchange of carbon dioxide between the atmosphere and the sea, Tellus, 12, 274-281, 1960.

Bradshaw, A. L., Brewer, P.G., Shafer, D. K., and Williams, R. T.: Measurements of total carbon dioxide and alkalinity by potentiometric titration in the GEOSECS program. Earth Planet, Sci. Lett., 55, 99-115, 1981.

Brewer, P. G.: Direct observation of the oceanic $\mathrm{CO}_{2}$ increase, Geophys. Res. Lett., 5, 997-1000, 1978.

Brewer, P. G.: Carbon Dioxide and the Oceans, in: Changing Climate, Report of the Carbon Dioxide Assessment Committee, National Academy Press, Washington, DC, 186-215, 1983.

Brewer, P. G.: What controls the variability of carbon dioxide in the surface ocean?, A plea for complete information, in: Dynamic Processes in the Chemistry of the Upper Ocean, NATO ARI, Jouy-en-Jossas, 1983, edited by: Burton, J. D., Brewer, P. G., and Chesselet, R., Plenum Press, New York, 215-281, 1986.

Brewer, P. G.: Ocean chemistry of the fossil fuel signal: The haline signature of "Business as Usual", Geophys. Res. Lett., 24, 13671369, 1997.

Brewer, P. G.: Foreword. In: "Ocean Biogeochemistry: The role of the ocean carbon cycle in global change", I -VIII, edited by: Fasham, M. J., Springer, 2003.

Brewer, P. G. and Goldman, J. C.: Alkalinity changes generated by phytoplankton growth, Limnol. Oceanogr., 21, 108-117, 1976. 
Brewer, P. G., Wong, G. T. F., Bacon, M. P., and Spencer, D. W.: An oceanic calcium problem? Earth Planet, Sci. Lett., 26, 81-87, 1975.

Brewer, P. G., Sarmiento, J. L., and Smethie, W. M.: The Transient Tracers in the Ocean (TTO) Program: The North Atlantic Study, 1981; The Tropical Atlantic Study, 1983, J. Geophys. Res., 90, 6903-6905, 1985.

Brewer, P. G., Friederich, G., Peltzer, E. T., and Orr, F. M. Jr.: Direct Experiments on the Ocean Disposal of Fossil Fuel $\mathrm{CO}_{2}$, Science, 284, 943-945, 1999.

Broecker, W. S. and Peng, T. H.: Tracers in the Sea, Eldigio Press, 690 pp., 1982.

Broecker, W. S., Takahashi, T. and Peng, T.-H.: Reconstruction of the past atmospheric $\mathrm{CO}_{2}$ contents of the contemporary ocean: An evaluation (US Department of Energy, Washington, DC) Rep. DOE/OR 857, 1985.

Bromley, D. A.: The President's Scientists: Reminiscences of a White House Science Advisor, Yale University Press, 273 pp., 1994.

Bruland, K. W. and Coale, K. H.: Surface water ${ }^{234} \mathrm{Th} /{ }^{238} \mathrm{U}$ disequilibria: spatial and temporal variations of scavenging rates within the Pacific Ocean, in: Dynamic Processes in the Chemistry of the Upper Ocean, NATO ARI, Jouy-en-Jossas, 1983, edited by: Burton, J. D., Brewer, P. G., and Chesselet, R., Plenum Press, New York, 159-171, 1986.

Buck, R. P., Rondini, S., Covington, A. K., Baucke, F. G. K., Brett, C. M. A., Camões, M. F., Milton, M. J. T., Mussini, T., Naumann, R., Pratt, K. W., Spitzer, P., and Wilson, G. S.: Measurement of pH. Definition, standards, and procedures. Pure Appl. Chem., 74, 2169-2200, 2002.

Burton, J.D., Brewer, P. G., and Chesselet, R., (Eds.): Dynamic Processes in the Chemistry of the Upper Ocean, NATO ARI, Jouyen-Jossas, 1983, Plenum Press, New York, 246 pp., 1986.

Byrne, R.H. and Breland, J. A.: High precision multiwavelength $\mathrm{pH}$ determinations in seawater using cresol red, Deep-Sea Res., 36, 803-810, 1989.

Caldeira, K. and Wickett, M. E.: Anthropogenic carbon and ocean pH, Nature, 425, 365 pp., 2003.

Caldeira, K., Akai, M., Brewer, P., Chen, B., Haugan, P., Iwama, T., Johnston, P., Kheshgi, H., Li, Q., Ohsumi, T., Poertner, H., Sabine, C., Shirayama, Y., and Thomson, J.: Ocean Storage, in: Carbon Dioxide Capture and Storage: A Special Report of IPCC Working Group III, Cambridge University Press, Cambridge UK, 2005.

Callendar, G. S.: The artificial production of carbon dioxide and its influence on temperature. Quarterly Journal Roy, Met. Soc., 64, 223-240, 1938.

Chen, C. T. and Millero, F. J.: Gradual increase of oceanic $\mathrm{CO}_{2}$, Nature, 277, 205-206, 1979.

Cicerone, R., Orr, J., Brewer, P. G., Haugan, P., Merlivat, L., Ohsumi, T., Pantoja, S., and Portner, H. O.: The ocean in a high $\mathrm{CO}_{2}$ world, Eos, 85, 351-353, 2004.

Clark, W. M.: The Determination of Hydrogen Ions, 3rd Edn., Williams and Wilkins: Baltimore, MD, 1928.

Dickson, A. G.: The measurement of sea water pH, Mar. Chem., 4, 131-142, 1993.

Dickson, A. G., Afghan, J. D., and Anderson, G. C.: Reference materials for oceanic $\mathrm{CO}_{2}$ analysis: a method for the certification of total alkalinity, Mar. Chem., 80, 185-197, 2003.
Dore, J.E., Lukas, R., Sadler, D. W., Church, M. J., and Karl, D. M.: Physical and biogeochemical modulation of ocean acidification in the central North Pacific, Proc. Natl. Acad. Sci. USA, 106, 12235-12240, 2009.

Dyrssen, D.: A Gran titration of seawater on board Sagitta, Acta Chem. Scand., 19, p. 1265, 1965.

Dyrssen, D. and Sillen, L. G.: Alkalinity and total carbonate in sea water: a plea for P-T independent data, Tellus , XIX, 113-121, 1967.

Edmond, J. M.: High precision determination of titration alkalinity and total carbon dioxide content of sea water by potentiometric titration, Deep-Sea Res., 17, 737-750, 1970.

Fairhall, A. W.: Accumulation of fossil $\mathrm{CO} 2$ in the atmosphere and the sea, Nature, 245, 20-23 (Erratum Nature v. 246, 106), 1973.

Fasham, M. J. R.: "Ocean Biogeochemistry: The role of the ocean carbon cycle in global change", Springer, 297 pp., 2003.

Forch,, C., Knudsen, M., and Sørensen, S. P. L.: Berichte über die Konstantenbestimmungenzur Aufstellung der hydrografischen Tabellen, K. Danske Vidensk, Selsk. Sk., 6. Raekke, Naturvidenske og Mathem. Afd., 12, 1-151, 1902.

Francois, R. E. and Garrison, G. R.: Sound absorption based on ocean measurements. Part II: Boric acid contribution and equation for total absorption, J. Acoust. Soc. Am., 72, 1879-1890, 1982.

Gattuso, J.-P., Frankignoulle, M., Smith, J. V., and Wollast, R., Coral reefs and carbon dioxide, Science, 271, 1298-1300, 1996.

Gattuso, J.-P., Frankignoulle, M., and Smith, S. V.: Measurement of community metabolism and significance in the coral reef $\mathrm{CO}_{2}$ source-sink debate, Proc. Natl. Acad. Sci. USA, 96, 13017$13022,1999$.

Goldman, J. C. and Brewer, P. G: Effect of nitrogen source and growth rate on phytoplankton-mediated changes in alkalinity, Limnol. Oceanogr., 25, 352-357, 1980.

Gorshkov, S. G. (Ed.): World Ocean Atlas, Volume 2, Atlantic and Indian Oceans, Pergamon, New York, 1978.

Handa, N. and Ohsumi, T.: Direct Ocean Disposal of Carbon Dioxide Terra Pub, Tokyo, 274 pp., 1995.

Haugan, P. M.: On the production and use of scientific knowledge about ocean sequestration, in: Greenhouse Gas Control Technologies, edited by: J. Gale and Y. Kaya, Pergamon, Elsevier UK, 1, 719-724, 2003.

Horibe, Y., Endo, K., and Tsubota, H.: Calcium in the South Pacific, and its correlation with carbonate alkalinity, Earth Planet. Sci. Lett., 23, 136-140, 1974.

Houghton, J. T., Jenkins, G. J., and Ephraums, J. J.: Climate Change: The IPCC Scientific Assessment, Cambridge University Press, 364 pp., 1990.

Houghton, J. T., Meira Filho, L. G., Callander, B. A., Harris, N., Kattenberg, A., and Maskell, K. (Eds.): Climate Change 1995: The Science of Climate Change, Cambridge University Press, 572 pp., 1996.

Jensen, W. B.: The symbol for pH, J. Chem. Educ, , 81, 21-22, 2004.

Johnson, K .M., King, A. E., and Sieburth, J. M. N.: Coulometric $\mathrm{TCO}_{2}$ analyses for marine studies: an introduction, Mar. Chem., 16, 61-82, 1985.

Keeling, C. D.: The influence of Mauna Loa observatory on the development of of atmospheric $\mathrm{CO}_{2}$ research, in: "Mauna Loa Ob- 
servatory: a 20th Anniversary Report", NOAA Special Report, 1978.

Kleypas, J. A., Buddemeier, R. W., Archer, D., Gattuso, J.-P., Langdon, C., and Opdyke, B. N.: Geochemical consequences of increased atmospheric carbon dioxide on coral reefs, Science, 284, 118-120, doi:0.1126/science.284.5411.118, 1999.

Kleypas, J. A., Buddemeier, R. W., and Gattuso, J.-P.: The future of coral reefs in an age of global change, Int. J. Earth. Sci., 90, 426-437, 2001.

Langdon, C., Takahashi, T., Sweeney, C., Chipman, D., Goddard, J., Marubini, F., Aceves, H., Barnett, H., and Atkinson, M. J.: Effect of calcium carbonate saturation state on the calcification rate of an experimental coral reef, Global. Biogeochem. Cy., 14, 639-654, 2000.

Lemon, E.: The Land's response to more carbon dioxide. In: "The Fate of Fossil Fuel $\mathrm{CO}_{2}$ in the Oceans", edited by: N. R. Andersen and A. Malahoff, Plenum Press, 749 pp., 1977.

Long, S. P., Ainsworth, E. A., Leakey, A. B., Nosberger, J., and Ort, D. R.: Food for thought: Lower-than-expected crop yield stimulation with rising $\mathrm{CO}_{2}$ concentrations, Science, 312, 19181921, 2006.

Marchetti, C.: On Geoengineering and the $\mathrm{CO}_{2}$ problem, Climatic Change, 1, 59-68, 1977.

Melillo, J. M., Callaghan, T. V., Woodward, F. I., Salati, E., and Sinha, S. K.: Effects on Ecosystems, CH. 10, 287-310, in: Climate Change: The IPCC Scientific Assessment, IPCC, Cambridge University Press, edited by: J. T. Houghton, Jenkins, G. J., and Ephraums, J. J., 364 pp., 1990.

PCAST (President's Council of Advisors on Science and Technology), 1997: Federal Energy Research and Development Agenda for the Challenges of the Twenty-First Century, US Dept. of Energy, Washington, DC, November.

Powers, E. B.: The physiology of the respiration of fishes in relation to the hydrogen ion concentration of the medium, J. Gen. Physiol., 305-317, 1922.

Redfield, A. C.: On the proportions of organic derivatives in sea water and their relation to the composition of plankton, James Johnstone Memorial Volume, Liverpool, 177-192, 1934.

Redfield, A. C. and Goodkind, R.: The significance of the Bohr effect in the respiration and asphyxiation of the squid, Loligo Pealei, J. Exp. Biol., 6, 340-349, 1929.

Revelle, R. and Suess, H. E.: Carbon dioxide exchange between atmosphere and ocean and the question of an increase of atmospheric $\mathrm{CO}_{2}$ during past decades, Tellus, 9, 18-27, 1957.
Riebesell, U., Zondervan, I., Rost, B., Tortell, P. D., Zeebe, R. E., and Morel, F. M. M.: Reduced calcification in marine plankton in response to increased atmospheric $\mathrm{CO}_{2}$, Nature, 407, 634-637, 2000.

Rubey, W. W.: Geologic history of seawater: An attempt to state the problem, Bull. Geol. Soc. Am., 62, 1111-1148, 1951.

Sabine, C. L. et al.: The oceanic sink for anthropogenic $\mathrm{CO}_{2}$, Science, 305, 367-371, 2004.

Sears, M. (Ed.): Oceanography, Am. Assoc. Advanc. Sci., Washington, DC, 654 pp., 1961.

Shirayama, Y. and Kogure, K.(Eds.): Special Section: Advances in biological research for $\mathrm{CO}_{2}$ ocean sequestration, J. Oceanogr., 60, 691-816, 2004.

Sillén, L. G.: The Physical Chemistry of Sea Water, in: Oceanography, M. Sears, ed., Am. Assoc. Advanc. Sci., Washington, DC, 1961

Sørensen, S. P. L.: Enzymstudien II: Uber die Messung und die Bedeutung der Wasserstoffionenkonzentration bei enzymatischen Prozessen, See especially, Biochem. Zeit, 21, 131-200, p. 134., 1909.

Sørensen, S. P. L. and Palitzsch, S.: Über die Messung die Wasserstoffionenkonzentration des Meerwassers, Biochemische Zeitschrift, 24, 387-415, 1909.

Sverdrup, H. U.,Johnson, M. W., and Fleming, R. H.: The Oceans: Their Physics, Chemistry, and General Biology, Prentice-Hall, 1087 pp., 1942.

Takahashi, T., Weiss, R. F., Culberson, C. H., Edmond, J. M., Hammond, D. E, Wong, C. S., Li, Y.-H., and Bainbridge, A. E.: A carbonate chemistry profile at the 1969 Geosecs intercalibration station in the eastern Pacific Ocean, J. Geophys. Res., 75, 76487666, 1970.

Turekian, K. K.: Results of the 1969 Geosecs test station. J. Geophys. Res., 75, p. 7639, 1970.

Wattenberg, H.: Über die Titrationsalkalinität und den Kalziumkarbonatgehalt des Meerwassers, Deutsche Atlantische Exped, Meteor 1925-1927, Wiss. Erg., Bd 8, 2 Teil, 122-231, 1933.

Whitfield, M.: Accumulation of fossil fuel $\mathrm{CO}_{2}$ in the atmosphere and the sea, Nature, 247, 523-525, 1974.

Wolf-Gladrow, D., Riebesell, U., Burkhardt, S., and Bijima, J.: Direct effects of $\mathrm{CO}_{2}$ concentration on growth and isotopic composition of marine plankton, Tellus, 51B, 461-476, 1999.

Zeebe, R. E. and Ridgwell, A.: Past changes in ocean carbonate chemistry. In: Ocean Acidification, edited by: J.-P. Gattuso and L. Hansson, Oxford, 326 pp., 2011. 